\title{
An Assessment of Anthropogenic Activity on the Pangolin Population in Deng-Deng National Park, Eastern Region, Cameroon
}

\author{
Melle Ekane Maurice ${ }^{1 *}$,Esong Lionel Ebong ${ }^{1}$, NasakoNoto Penda $^{1}$, Manjo Chiara Keafon ${ }^{2}$, \\ Asongtia Camille Awuanuge ${ }^{2}$, OlleAmbe Flaubert Gildas ${ }^{2}$ \\ ${ }^{I}$ Department of Forestry and Wildlife, University of Buea, Cameroon. \\ ${ }^{2}$ Conservation Action Research Network (CARN) for the Congo Basin, Central African Region.
}

*Corresponding Author: Melle Ekane Maurice, Department of Forestry and Wildlife, University of Buea, Cameroon.

\begin{abstract}
The widespread commercialization of pangolins has posed the greatest threat to its conservation as a result of increasing demand from international markets. This overexploitation is one of the main pressures driving the pangolin population into a decline.. Though pangolins are used for several purposes, all the purposes for which they are used are however not important in ensuring its regeneration and sustainability. The aim of this research was to investigate the anthropogenic activities affecting the ecology of pangolins and other wildlife species in the national park. The data collection method was done by the administration of questionnaires to a randomly chosen population in the 9 villages located in the national park. The study has shown a significant correlation between hunting and farming, $r=0,860 P<0.05$. A significant relation between hunting activity and age-class, $\chi^{2}=8.614, d f, P<0.05$, has shown that almost all the age-classes considered for this survey from subadults to adults are seriously involved in hunting. Farming and age-class has also shown a significant association, $\chi^{2}=33.836 d f=5 P<0.05$. In addition, the survey equally showed a significant relation, $\chi^{2}=13.962$ $d f=3 P<0.05$, between educational level and farming practice. The study recorded $38.67 \%$ on snares, believed to be set by the local hunters and trappers. However, this was not a surprise to anybody since the local villagers are using these animals for bush meat consumption and revenue generation for household. An encounter rate of $26.67 \%$ for empty bullet-shells was an additional confirmation of heavy poaching in this protected area, necessitating the need for a new conservation strategy. An anthropogenic survey would be needed to establish the reasons for this serious poaching and trapping.
\end{abstract}

Keywords: Pangolin population, anthropogenic activity, Hunting, Farming, Snares, Trappers.

\section{INTRODUCTION}

All pangolin species are at risk of extinction due to rapid increase in trafficking, poaching, overhunting and habitat loss. They are presently the most trafficked wild mammals in the world, with over 1 million pangolins estimated to have been poached and trafficked within the last decade (MENTOR-POP Report, 2017). The exhaustion of Asian pangolins has increased the pressure on the African species, provoking the already existing issue of hunting and illegal wildlife trade. Reports on the interception and seizures of pangolins and its derivatives in Africa and particularly in Cameroon lately, explains the pressure and threat faced by the resource. Just like several other parks and reserves in Cameroon, the Deng-Deng National Park is a forest region which, though protected, the pangolin presence is gradually dwindling. It is on the basis of this that there is need for unraveling information pertaining to the status, trend and threats to pangolins in deng-deng national park. This will create the basis for making evidence-based management decisions by engaging in on spot long term monitoring of the threatened species in the park. Pangolins are the only scaly mammals (Challender et al., 2012, 2014). They are eight extant species of pangolins, four species occur in Asia and four in Africa with three of the African species; giant ground pangolin (Smutsiagigantean), white-bellied pangolin (Phataginustricuspis), and black-bellied pangolin(Phataginustetradactyla) present in Cameroon. They are primarily nocturnal, foraging for ants and termites during the night and resting in tree hollows and burrows during the day (IUCN Pangolin Group, 2016, Chao et al., 2005). 
An Assessment of Anthropogenic Activity on the Pangolin Population in Deng-Deng National Park, Eastern Region, Cameroon

Pangolin conservation efforts in Central Africa are hampered by lack of information on their populations, natural history, threats, and the wildlife trade. This is because pangolins are rarely included in mammal surveys in Central Africa. The pangolins of African lowland forests and savanna gallery forests remain one of the planet's least studied animals (Kingdon, Hoffmann, \& Hoyt, 2013). Whatever little information there is, describes only an animal that is largely nocturnal, burrowing, and primarily restricted to remote areas where hunting pressure is low. Populations of Asian pangolins have greatly reduced and traffickers have turned to Africa to source for pangolins. While there have been increasing efforts to conserve pangolins in recent years, effective conservation of pangolins require knowledge of the ecology pangolins in the wild. In addition, there is no established protocol for pangolin population assessment. However, this barrier is gradually being remedied by the Pangolin Conservation Network (PCN) through its research activities and interconnectedness in information sharing on the status of pangolins across the globe and designing measures of redressing the problems. In comparison to Asian pangolins, less is known about the African species: whitebellied pangolins (Phataginustricuspis), black-bellied pangolin (Phataginustetradactyla), giant ground pangolin (Smutsiagigantea) and temminck's ground pangolin (Smutsiatemminckii). They are currently classified as 'vulnerable' by the IUCN (Pietersen et al. 2014a), and international trade was recently banned (CITES 2016). The African speciesare also threatened by consumptive use in the West, Central and Southern Africa (Soewu and Ayodele, 2009; Soewu and Adekanola, 2011). There are periodic calls from CITES and the IUCN Pangolin Specialists Group for members to provide information about population trends and distribution in their countries or areas in which they work. This project will therefore contribute in efforts to furnish Cameroon's Ministry of Forestry and Wildlife (MINFOF) and conservation organizations with information about pangolin population.

Like elephants and pandas, pangolins are edge species (evolutionarily distinct and globally endangered), meaning they have few close relatives and represent a disproportionate amount of unique evolutionary history (Zhou et al.2014). Threats to pangolins generally can be seen within the aspects of habitat degradation, overexploitation, illegal tradeand its solitary nature. They are morphologically distinct from all other mammals in that they are covered in an armor of keratinous scales. Their biological attributes make them extremely vulnerable to over-exploitation by humans because they are easily hunted, have a low reproductive rate and low density, and do not survive or breed readily in captivity (Gaubert 2011; Yanget al. 2007).

In terms of pangolins traditional uses, they have been traditionally hunted by different tribal communities throughout its geographical range for variety of purposes; especially for ethno-medical uses. For instance, In India, some ethnic groups believe that scales and claws of Indian pangolins possess antiseptic properties, and thus use pangolin claws to pierce boils or skin abscess, and ointments made of pangolin scales to heal wounds and inflammations (Mohapatra et al., 2015). Bile of the Indian pangolins is used by some communities in Arunachal Pradesh of India to cure the splenomegaly (Chinlampianga et al., 2013) while some forest-dwelling tribes in Orissa, India are known to wear rings made of Indian pangolin scales as a remedy for piles/haemorrhoids (Mishra and Rout, 2009). Indian pangolin scales are also believed to have nematocidal properties (Betlu, 2013). In Nepal, some communities consider pangolin flesh as a remedy for asthma and rheumatic fever, while oil extracted from pangolin scales is used to treat bone and muscle disorders (Kaspal, 2010). Pangolin scales are also used by tribal ethno-medical practitioners in treating infertility in women (Katuwal et al., 2013). Cultural and mythical beliefs of certain tribal communities have also caused Indian pangolin populations to decline over the years in Nepal. For instance, using pangolin scales in children's jewelries is believed to protect them from evil spirits, and wearing pangolin scales is believed to bring luck (Katuwal et al., 2013). In Pakistan, traditional and ethno-medical practitioners also value pangolin body parts as ingredients for variety of traditional medicines (Roberts, 1997).

\section{MAterials AND Methods}

\subsection{The Description of the Study Area}

The Deng-Deng National Park is found in the East Region of Cameroon and covers a surface area of approximately 68,264 hectare. It is located between $5^{\circ} 21^{\prime} 2.8^{\prime \prime} \mathrm{N}$ to Longitude $13^{\circ} 26^{\prime} 30.4^{\prime \prime} \mathrm{E}$ (Maisels et al., 2010a). It has mean monthly daily temperatures of about $34^{\circ} \mathrm{c}$ during the dry season. During the wet season, temperature falls to a daily mean of about $22^{\circ} \mathrm{C}$, with the peak of rainfall 
An Assessment of Anthropogenic Activity on the Pangolin Population in Deng-Deng National Park, Eastern Region, Cameroon

recorded at about 2500mm in August (Maisels et al., 2010a). The national park has savanna ecosystem and forest vegetation found at the northern and southern regions. The national park equally has diverse species of wildlife population, such as gorillas, chimpanzees, monkeys, antelopes, golden cats, porcupines, squirrels, red river hogs, duikers, and several others. This has made the park an attractive zone for research (Maisels et al., 2010a).

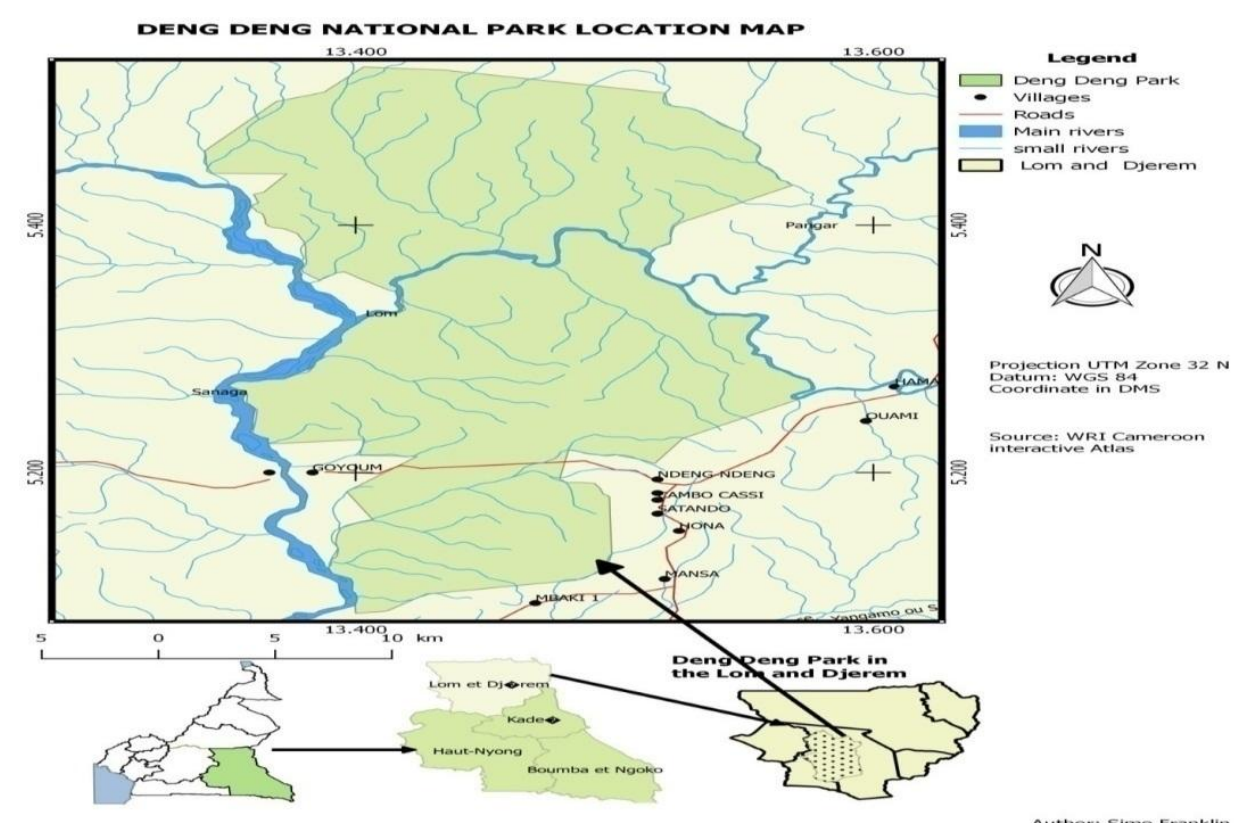

Figure1. Location of Study Area (Source: Maisels Et Al., 2010a)

\subsection{Data Collection Method}

The socio-economic survey conducted in local communities surrounding deng-deng national park was done with the aid of semi-structured questionnaires. A total of 238 questionnaires were administered in 9 villages (Lom-Pangar, Ouami, Haman, Deoule, Deng-Deng, Goyoum, Mbaki I, Mbaki II, and Kambo-Cassi). These villages are located at the periphery of the national park. The questionnaires were written in English and translated into the French language, the main language spoken in the area. The process of questionnaire administration was done for a period of two weeks, and all the questionnaires handed to the respondents were collected. Data from community surveys were compared with data from field surveys in order to determine the extent to which the local ecological knowledge was able to provide knowledge on key pangolin conservation parameters (Haenet al., 2014).The method that was used during data collection was adapted from Nash et al. (2016), who conducted community-based surveys on pangolins in Hainan, China.

Interviews were also conducted together with the help of semi-structured questionnaires made up of both open-ended and closed questions. The interviews were conducted with the aid of a local inhabitant; someone with good local knowledge, who spoke the local language and whom locals trusted and felt comfortable speaking with. Four villages were surveyed in the protected area. These villages were selected amongst villages that were located close to the areas in which field surveys were carried out and which share boundaries or were located very close to the national park. At least ten persons were interviewed in each of the selected villages. Efforts were made to identify respondents deemed to have good knowledge of the wildlife in the area. In each village, the first respondents were selected with the help of a guide while subsequent respondents were selected using snow ball sampling. At the end of each interview, respondents were asked to direct the research team to persons they thought had good knowledge about the wildlife of the area.

The first section of questionnaire addressed demographic information such as sex, age, educational levels. The rest of the questionnaire contained questions on wildlife poaching. After responding to questions aimed at collecting demographic data, respondents were shown colour photographs of animals in succession during which time questions pertaining to each animal were asked. Respondents were asked whether or not they recognized these animals and whether or not these animals currently 
An Assessment of Anthropogenic Activity on the Pangolin Population in Deng-Deng National Park, Eastern Region, Cameroon

exist or had existed in the past in the protected areas. After having shown photographs of each animal species, respondents were also asked to provide further ecological and morphological details to confirm accurate recognition. In addition, the presence of hunting tracks, wood exploitation roads, bullet-shells, hunters' camps, and several gun-shots heard during the night period were recorded.

\subsection{Data Analysis}

The research data of this study was analyzed using both exploratory and inferential statistical models. The demographic data such as age-class was tested on occupational data such as farming, hunting, and education inferentially. The comparison of hunting on the farming activity was done by using exploratory model techniques. The obtained results were displayed in tables and figures.

\section{RESUltS}

This study has shown a respondent of $58 \%$ on farming activity, while the hunting activity recorded $22 \%$ (tab. 1). The main source of protein for the inhabitants of this area is bush meat since beef and fish sold in the local markets are not affordable by many because of the high cost. It is believed that these people are involved in many social activities like petit trading, but the study only considered the most predominant activities. In addition, it was noted in the study that the people in Deng-Deng National Park (DDNP) have a good practical knowledge on the ecology of pangolins. Most of them, even though not hunters had already captured at least one pangolin, either during nocturnal walks or during field work. The all the respondents accepted they have knowledge on the white-bellied pangolin and also know its ecological attributes such as its nocturnal life-style and its ant and termite diet. Many said, they do not know the black-bellied pangolin, but those who recognized it said it is diurnal and very rare in the region. The giant pangolin is as well-known as the white-bellied pangolin, mostly present in the savannah but reported as being in very strong decline. The village population for the most part did not know the price of a giant pangolin with the exception of those who go to Bertoua city for wildlife trade. However, the villagers have shown a very high level of awareness and some think that pangolins may disappear one day, hence, appreciate the initiative of pangolin conservation for future generations.

Table1. Anthropogenic Activity

\begin{tabular}{|ccc|}
\hline VARIABLES & FREQUENCY & PERCENTAGE (\%) \\
\hline Hunters & 17 & 22.7 \\
Farmers & 58 & 77.3 \\
Total & $\mathbf{7 5}$ & $\mathbf{1 0 0}$ \\
\hline
\end{tabular}

There is a significant correlation between hunting and farming, $\mathrm{r}=0,860 \mathrm{P}<0.05$ (fig. 2). This is a confirmation that farming and hunting are in existence in this area and the people are very much involved into these activities simultaneously. The local inhabitants of this area practice local cropfarming but majority are hunters.

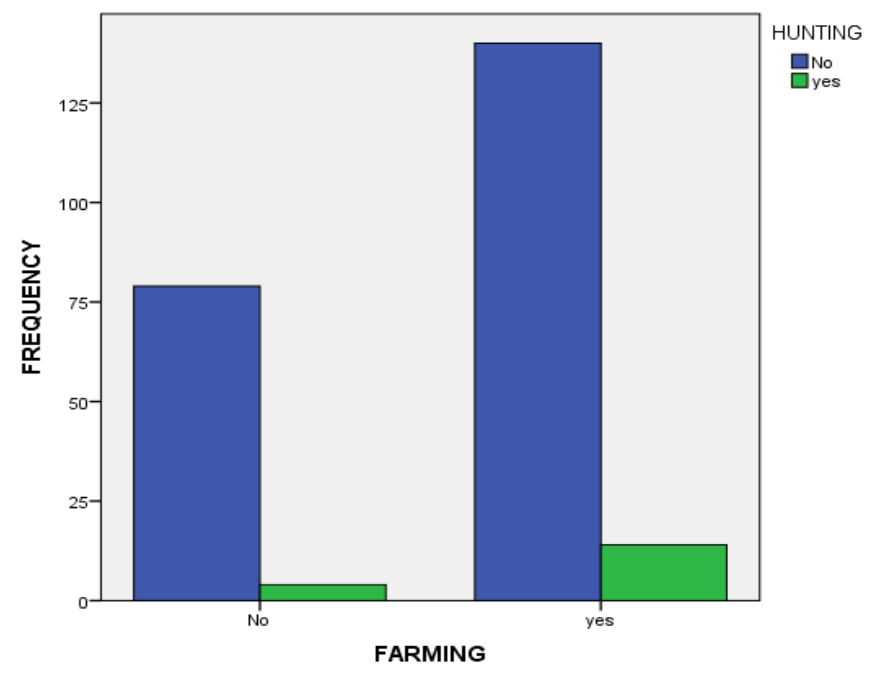

Figure2. Hunting and Farming Activities 
A significant relation between hunting activity and age-class, $\chi^{2}=8.614$, $\mathrm{df} \mathrm{P}<0.05$, has shown that almost all the age-classes considered for this survey from sub-adults to adults are seriously involved in hunting (fig. 3). The hunting activity is more of a tradition than an occupation in a typical village setting in many parts of Cameroon. Young people, especially the male children are groomed into the hunting activity from infancy; grow up with the hunting tradition, making it a predominant activity in life.

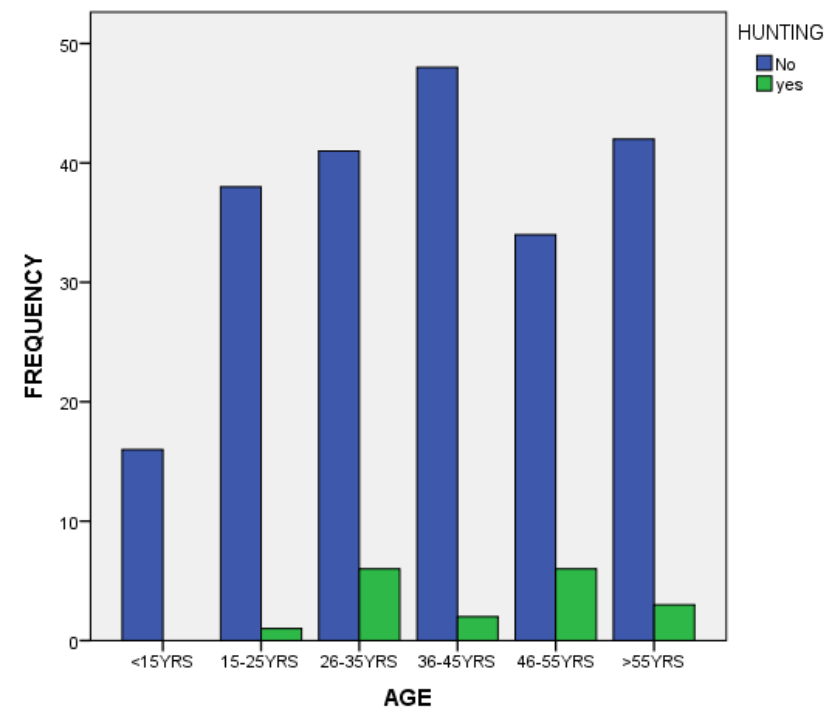

Figure3. Hunting Activity and Age-Class.

Farming and age-class has also shown a significant association, $\chi^{2}=33.836 \mathrm{df}=5 \mathrm{P}<0.05$ (fig. 4). Just like the hunting activity, farming is an activity that children in Cameroon villages are groomed into from childhood. Hence, a child learns local farming skills from parents and from schools as a means of survival in the system. The economic strength of an average Cameroonian in the village area is rooted strongly into local farming, an activity that helps them generate income for their well being.

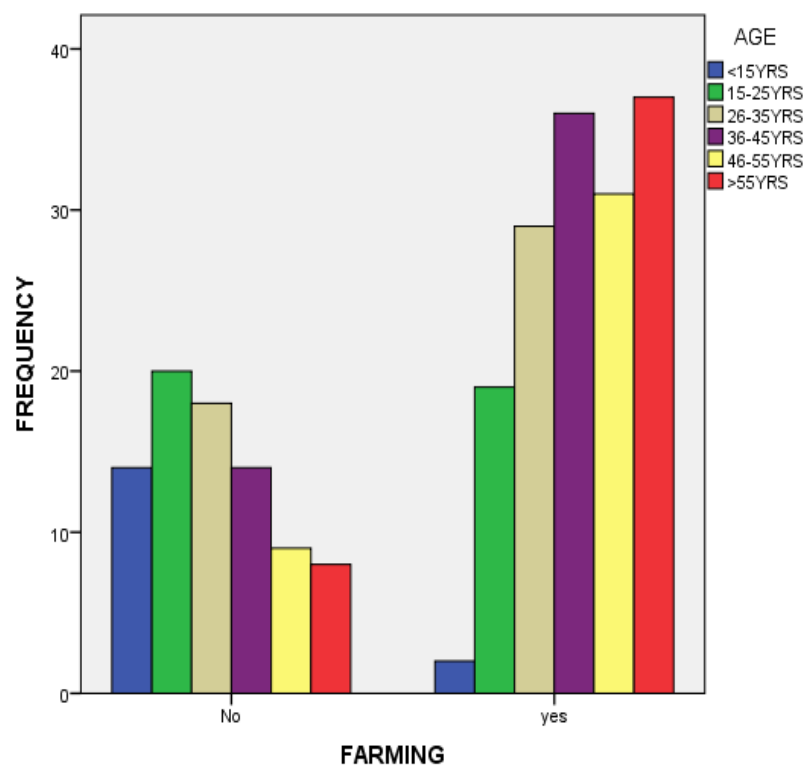

Figure4. Farming and age-class

The survey has equally shown a significant relation, $\chi^{2}=13.962 \mathrm{df}=3 \mathrm{P}<0.05$, between educational level and farming (fig. 5). Education has contributed immensely in advancing local farming activities in Cameroon. Most farmers are trained through the agricultural extensive workers in work-shops in order to enhance their farm production. 


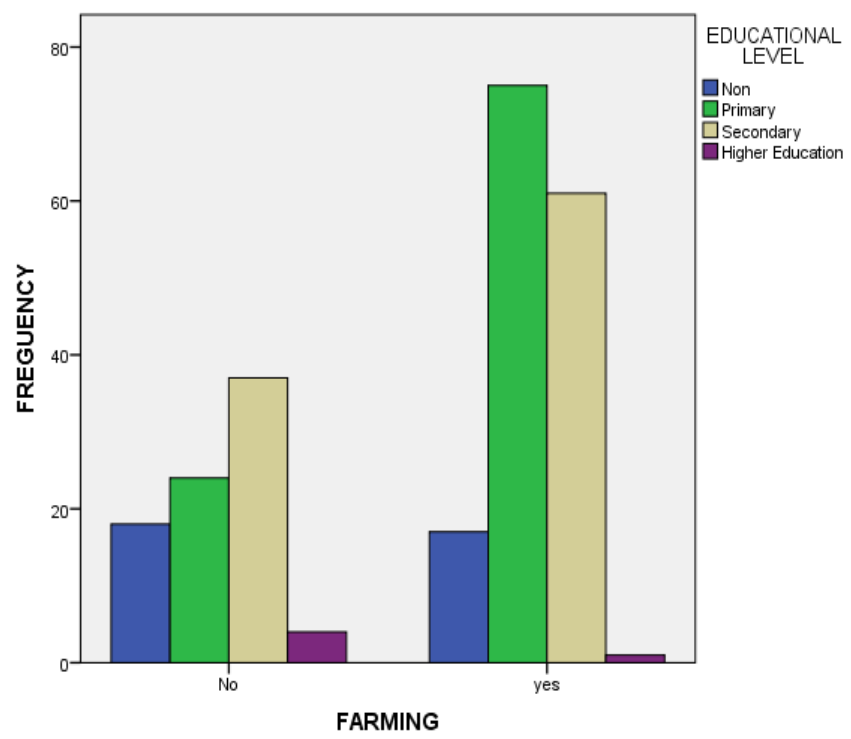

Figure5. Farming and Educational Level

The study recorded $38.67 \%$ on snares, believed to have been set by the local hunters and trappers (fig.6). However, this would not be a surprise to anybody since the local villagers are using these animals for bush meat consumption and revenue generation for household. Beef does not exist in some of the villages visited by the research team; otherwise villagers would need to cover long distances looking for beef to buy in neighboring towns. One of the main problems faced by villagers in most villages in Cameroon is having beef from cattle headers. Most villagers living in villages in some parts of Cameroon are very poor, for this reason the cattle trade for beef in such places is discouraging. Historically, most villages have been dependent on the gathering of forest resources, hunting and trapping of wildlife for household survival. Changing this culture would mean the evolution of animal husbandry at a large scale should be introduced and financed by the national government in villages found in the peripheral zone of the protected areas. An encounter rate of $26.67 \%$ for empty bullet-shells was an additional confirmation of heavy poaching in this protected area, necessitating the need for a new conservation strategy. An anthropogenic survey would be needed to establish the reasons for this serious poaching and trapping. Sporadic gun-shots recorded a frequency rate of $8.00 \%$ during the study, another confirmation of the ineffectiveness of wildlife protection by the wildlife management authorities in the national park.

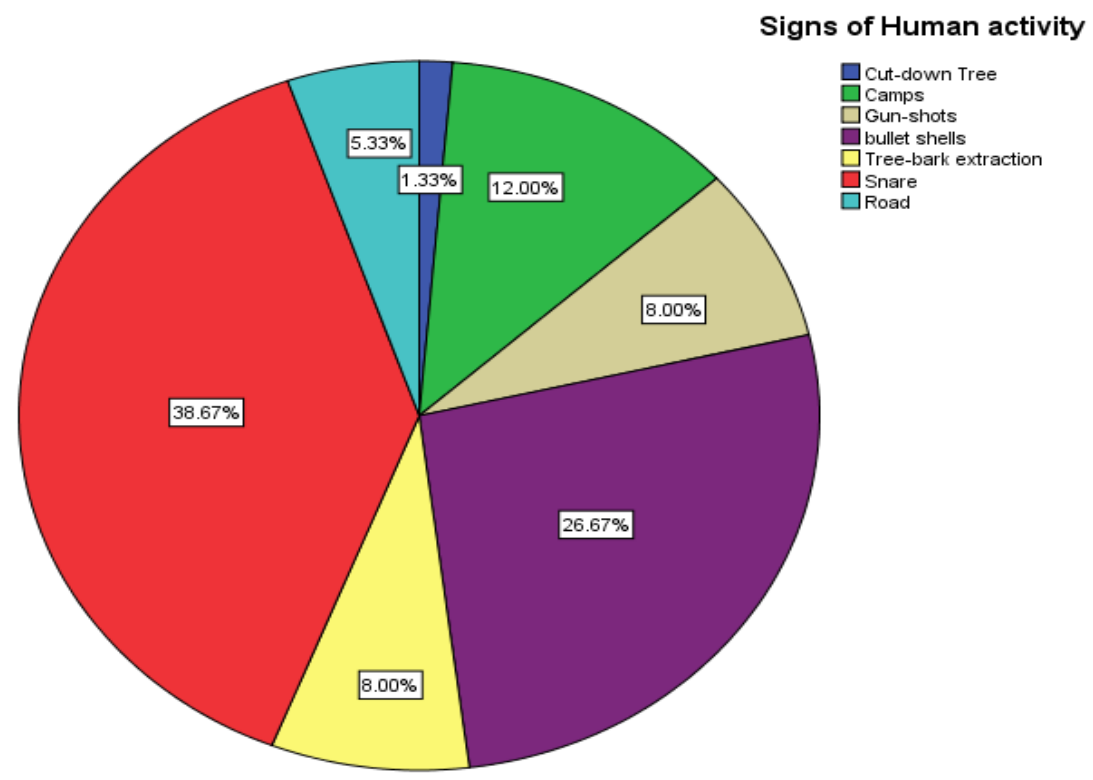

Figure6. The signs of human activity in the national park 
An Assessment of Anthropogenic Activity on the Pangolin Population in Deng-Deng National Park, Eastern Region, Cameroon

\section{DISCUSSION}

Over exploitationis one of them inpressures causing species' declines and local extinctions (Maxwelletal.2016; Ducatez\&Shine2017). Informationon wildlife harvests can be d ifficult to collect because, attimes, hunters and traffickers operate secretly to avoid law enforcement officers, and may be unwillingto disclose what they have harvested(Keaneetal.2008).Law enforcement pangolin seizure data $\mathrm{have}$ been used to quantify exploitation of threatened species; however, these data suffer from detection biases and underestimation(Gavin etal.2010).Pangolins(Family: Manidae), a group of African and Asian scaly mammals, are considered to be "the most heavily trafficked wild mammalin the world," and are hunted and traded for food and traditional medicines(Challenderetal.2014). They areal souse dinrituals, art, and magic among communities across Africa(Soewu\&Sodeinde2015) and Asia(Mahmoodetal.2012). Despite along history of exploitation, pangolin populations in Asia have declined dramatically, estimated90\% decline of Chinese pangolin (Manispentadactyla) since the 1960s (Wuetal.2004). All four Asian pangolin species are listed as"Critically Endangered"or"Endangered" on the International Union for Conservation of Nature(IUCN) RedList of Threatened Species due top at, present, and predicted population declines driven by growing demand for meat and scales(Challenderetal. 2014), and compounded by lower productiverates(Newtonet al.2008; Challenderetal.2012; Chenge tal.2017). In addition, commercial trade and international trade of wild-caught pangolins have been banned (CITES2016).

Most respondents based their estimations from the number of pangolins recently encountered on village roads, bush markets and forest in deng-deng national park region. Generally, more respondents felt that the population of the giant pangolins (Smutsiagigantea) and black-bellied pangolins (Phataginustetradactyla) were at the brink of extirpation while that of the white-bellied pangolins (Phataginustricuspis) was increasing in the national park eco-zone. In the past, pangolins were hunted just for their meat but today pangolins are hunted for both their meat and scales. Almost everyone knows the commercial value of pangolin scales, an additional motivation for the poaching of pangolins in deng-deng national park area. The availability of pangolins in villages and markets may not necessarily be as a result of the increase in population but as a result of increase in hunting pressure to fuel the trade.

Intense hunting to supply the illegal wild life trade has severely depleted the biodiversity of Asian tropical forests(Faetal.2002). Although people have hunted mammals in these habitats for thousands of years, regional declines in most species have occurred largely within the last half century(Corlett2007).As the market value of wildlife has escalated with increasing demand and decreasing supply, hunting purely fortrade has eclipsed hunting primarily for subsistence(Sterling etal.2006).Over the past2 decades,Vietnamhas become an important link in the international wildlife tradenet-work, acting as a conduit fore xports from other South-east Asian countries, suchas LaoPDR, Cambodia and Myanmar,to international markets in Asia, Europe and America(Belletal.2004).

Many respondents in this survey reported having caught pangolins by simply handpicking in nearby forests and along footpaths close to their houses. This suggest that pangolins species in Central Africa can tolerate moderate level of human disturbance just like the Palawan pangolin suggested by Marler (2016). The high volumes and frequencies of observation in villages leave local inhabitants with the perception that pangolins population are increasing and that pangolins could not be hunted to extinction. Pangolin meat is a source of protein to many local households as the meat is said to be very tasteful. It is also a source of income as the entire pangolin is sometimes sold with scales or cut into smaller more affordable slices, prepared and sold in the village markets. Many of the scales are sold in the 'black market' while some traditional practitioners also use pangolin scales for traditional medicine in Cameroon. In the past, the scales of the pangolins were used to chase away evil spirits in the MbametDjerem National Park. CITES (2000), Duckworth et al., (2008) and Suwal (2011), discussed that poaching and habitat destruction are important factor for the decline of pangolin population. Seizures of pangolins and their derivatives (scales and skins) from Africa destined for Asia are increasing (Heinrichetal.2016) with over 53 tons seized in 2013 (Flocken2015), and more than 1 million pangolins trafficked globally since 2000 as estimated from illegal trade data 
An Assessment of Anthropogenic Activity on the Pangolin Population in Deng-Deng National Park, Eastern Region, Cameroon

IUCNSSC PangolinSpecialist Group (2016). These estimates likely represents fraction of all pangolinstraded,and even smaller proportion of the number of pangolins hunted. Many studies have monitored wildlifehuntingand/ormarketsat local scales across Africa (Crookese tal. 2006; Coad etal.2013).

\section{CONClusion}

In comparison to Asian pangolins, less is known about the African specie: white-bellied (Phataginustricuspis), black-bellied (Phataginustetradactyla), giant ground(Smutsiagigantea), and Temminck's ground pangolin(Smutsiatemminckii).African pangolin population is presumed to be declining,because of habitat degradation and heavy hunting pressure caused mainly by increasing demand from international markets. Pangolin hunting is common as they don't fight back and are easy to catch with simple hunting tools like traps or simple hand held tools like sticks and machetes or simply picked up with the hand in the case of the white-bellied pangolin. Apart from poaching and hunting, rapid loss and deterioration of habitats, agricultural expansions, use of pesticides and road-kills are among the numerous threats to the survival of pangolins in Cameroon. The quest for pangolins to feed the domestic demand for meat and the international demand for scales is giving high motivation to hunters in deng-deng national park area to mount more poaching pressure on the vulnerable and solitary wildlife species with very low reproductive rate.

\section{REFERENCES}

[1] BellD, RobertonS, Hunter PR(2004)Animal origins of SARS coronavirus: possible links with the internationaltradeinsmallcarnivores.PhilosTransRSocB359:1107-1114

[2] Betlu, A. L. S. (2013). Indigenous knowledge of zootherapeutic use among the biate tribe of dimahasao district, assam, northeastern india. Journal of ethnobiology and ethnomedicine, 9, 1.

[3] Challender, D. W. S., Waterman, C., \& Baillie, J. E. M. (2014). Scaling up pangolin conservation. IUCN SSC Pangolin Specialist Group Conservation Action Plan. Zoological Society of London, London, UK

[4] Challender, D.W.S., Baillie, J.E.M., Waterman, C., the IUCN-SSC (2012). Pangolin Specialist Group. (2012).

[5] Chao, J. T., Tsao E. H., Holzer, K. T., Reed, D., Leus, K., (eds.). (2005). Formosan Pangolin Population and Habitat Viability Assessment: Final Report. IUCN/SSC Conservation Breeding Specialist Group, Apple Valley, MN.

[6] Chinlampianga, M., Singh, R. K. \& Shukla, A. C. (2013). Ethnozoological diversity of northeast india: Empirical learning with traditional knowledge holders of mizoram and arunachalpradesh. Indian Journal of Traditional Knowledge, 12, 18-30.

[7] CITES. (2016). Consideration of proposals for amendmentof appendices i and ii [Online]. Available:https://cites.org/sites/default/files/eng/cop/17/prop/060216/E-CoP17-Prop-11.pdf Accessed 3 May 2017.

[8] CITES. (2000). Prop. 11.13. Maniscrassicaudata, Manispentadactyla, Manisjavanica. Transfer from Appendix II to Appendix I (India, Nepal, Sri Lanka, UnitedStates). Available at: http://www.cites.org/eng/cop/11/prop/13.pdf.

[9] Coad, L.,Schleicher, J.,Milner-Gulland, E.J.,etal.(2013). Social andecological change over adecadeina village hunting system,central Gabon.Conserv.Biol.,27,270-280.

[10] CITES (2016). Consideration of Proposals for Amendments to Appendices I and II in the Seventeenth Meeting of the Conference of the Parties (CoP17) to be held in Johannesburg, South Africa from September 24 - October 5, 2016.

[11] CorlettRT(2007)The impact of hunting on the mammalian fauna of tropical Asian forests.Biotropica39:292-303

[12] Crookes,D.J.,Ankudey,N.\&Milner-Gulland,E.J.(2006). The value of along-termbush meat market data set as an indicator of systemdynamics.Environ.Conserv.,32, 333-339.

[13] Crookes,D.J.,Ankudey,N.\&Milner-Gulland,E.J.(2006). The value of along-termbush meat market data set as an indicator of systemdynamics.Environ.Conserv.,32, 333-339.

[14] Ducatez,S.\&Shine,R.(2017).Drivers ofextinctionriskinterrestrialvertebrates.Conserv.Lett.,10,186-194.

[15] Duckworth,J.W., Steinmitz,R., Pattanavibool,A.,ThanZaw,Do Tuoc\&Newton,P.2008.Manis pentadactyla.In:IUCN2012. IUCN Red List of Threatened Species. Version 2012.1.

[16] FaJE,PeresCA,MeeuwigJ(2002) Bushmeatexploitation intropical forests:an intercontinental 
An Assessment of Anthropogenic Activity on the Pangolin Population in Deng-Deng National Park, Eastern Region, Cameroon

comparison.ConservBiol16:232-237

[17] Gavin, M.C.,Solomon,J.N.\&Blank, S.G.(2010).Measuringand monitoring illegal use of natural resources. Conserv.Biol.,24,89-100.

[18] Flocken,F.(2015).Listing pangolins under US Endangered Species Act.http://www.ifaw.org/ unitedkingdom/news/listing-pangolins-under-us-endangered-species-act. Accessed 18December2016.

[19] Haen,N.,Schmook, B.,Reyes,Y.,Calme,S.,(2014).Improving conservation outcomes within sights from local experts and bureaucracies.Cons. Biol. 28,951-958.

[20] Heinrich, S., Wittmann, T. A., Prowse, T. A., Ross, J. V., Delean, S., Shepherd, C. R. and Cassey, P. (2016). Where did all the pangolins go? International CITES trade in pangolin species. Global Ecology and Conservation 8:241-253.

[21] IUCNSSC Pangolin Specialist Group.(2016).The conservation status, illegal trade and useofpangolins(Manisspp.).Information document for the $66^{\text {th }}$ meeting of the CITES standing committee,11-15January2016,Geneva,Switzerland,pp1-8. Accessed 3February2017.

[22] Kaspal, P. (2010). Saving the pangolins: Ethno zoology and pangolin conservation awareness in human dominated landscapes of nepal. Proceeding of the First One Day National Seminar on Small Mammals Issues, (2010). 43-58.

[23] Katuwal, H. B., Neupane, K. R., Adhikari, D. \&Thapa, S. (2013). Pangolins trade, ethnic importance and its conservation in eastern nepal. Small Mammals Conservation and Research Foundation and WWFNepal, Kathmandu, Nepal.

[24] Keane,A.,Jones,J.P.G.,Edwards-Jones,G.\&Milner-Gulland,E.J.(2008).The sleeping policeman: understanding issues ofen forcement and compliance in conservation.Anim.Conserv.,11,75-82.

[25] Kingdon,J.S.,Hoffmann,M.,\&Hoyt,R.(2013).Smutsiagigan tea Giant Ground Pangolin.In:J.S.Kingdon,\& M.Hoffmann(Eds.).The mammals of Africa.Volume5:Carnivores,pango- lins, equids, rhinoceroses (pp. 396-399). London, England: Bloomsbury Publishing.

[26] Mahmood,T.,Hussain,R.,Irshad,N.,Akrim, F.\&Nadeem,M.S.(2012).Illega masskilling of Indian pangolin(Maniscrassicaudata)inPotoharregion,Pakistan.Pak.J.Zool., 44,1457-1461.

[27] Maisels, F., R. Ambahe, E. Ambassa, B. Fosso, J. B. Pouomegne and R. Fotso (2010a). Wildlife and human impact surveys of the Deng Deng National Park and UFA 10065, 2010. WCS Cameroon, Yaounde, Cameroon.

[28] Marler, P. N. (2016). Camera trapping the palawan pangolin manisculionensis (mammalia: Pholidota: Manidae) in the wild. Journal of Threatened Taxa, 8, 9443-9448.

[29] Maxwell,S.L.,Fuller,R.A.,Brooks,T.M.\&Watson,J.E.M.(2016).The ravages of guns, nets andbulldozers. Nature, 536,143-145.

[30] Mentor-Pop Report (2017). Pangolin Conservation in Central African Region.

[31] Mishra, N. \& Rout, S. (2009). Ethno-zoological studies and medicinal values of similipal biosphere reserve, orissa, india. African Journal of Pharmacy and Pharmacology, 5, 6-11.

[32] Mohapatra, R. K., Panda, S., Nair, M. V., Acharjyo, L. N. \&Challender, D. W. (2015). A note on the illegal trade and use of pangolin body parts in india. Traffic Bulletin, 27, 33

[33] Nash H.C, Wong M.H.D.G., Turvey S.T. (2016). Pangolins: Natural Pest Controllers and Soil Caretakers. Retrieved July 7, 2016 from http://www.pangolins.org/2011/11/01/pangolins-natural-pest-controllers-andsoil-caretakers/

[34] Newton,P.,Nguyen, V.T.,Roberton,S.\&Bell,D.(2008). Pangolins in peril: using local hunters knowledge to conserveelusive species in Vietnam. Endangered.SpeciesRes.,6,41-53.

[35] Pietersen,D.,Waterman,C.,Hywood, L.,Rankin,P.\&Soewu,D.(2014).Smutsiatemminckii.TheIUCNRedListofThreatenedSpecies 2014:e.T12765A45222717.https://doi.org/10.2305/IUCN.UK.20142.RLTS.T12765A45222717. en. Accessed 13December2016.

[36] Soewu,D.A.\&Sodeinde,O.A.(2015).Utilization of pangolins in Africa:fuelling factors, diversity of uses and sustainability.Int.J.Biodivers.Conserv.,7,1-10.

[37] Soewu D.A,\&Adekanola TA (2011) Traditional-medical knowledge and perception of pangolins (Manissps) among the Awori people, Southwestern Nigeria. Journal of Ethnobiology and Ethnomedicine 7: 25-35. doi: 10.1186/1746-4269-7-25 PMID: 21884607

[38] Soewu D. A \&Ayodele L.A. (2009). Utilization of Pangolin ( ManisSpp) in traditional Yorubic Medicine in Ijebu Province. Ogun State, Nigeria. Journal of Ethnology and Ethnomedicine 5: 39-49

[39] SterlingEJ, HurleyMM,\&LeMD (2006) Vietnam — a natural history. Yale University Press, New 
An Assessment of Anthropogenic Activity on the Pangolin Population in Deng-Deng National Park, Eastern Region, Cameroon

\section{Haven, CT}

[40] Roberts, T. (1997). The mammals of pakistan (revised ed.) oxford university press. Karachi, Pakistan, 525.

[41] Wu, S., Liu, N., Zhang, Y., and Ma, G. Z. (2004). Assessment of thr eatened status of Chinese Pangolin (Manispentadactyla). Chinese Journal of Applied and Environmental Biology, 10(4), 456-461

[42] Yang, C. W., Chen, S., Chang, C. Y., Lin, M. F., Block, E., Lorentsen, R., Chin, J. S. \&Dierenfeld, E. S. (2007). History and dietary husbandry of pangolins in captivity. Zoo biology, 26, 223-230.

[43] Zhou, Z.M., Zhou, Y., Newman, C., MacDonald, D.W., (2014). Scaling up pangolin protection in China. Front. Ecol. Environ. 12, 97-98.

Citation: Melle Ekane Maurice, et.al., “An Assessment of Anthropogenic Activity on the Pangolin Population in Deng-Deng National Park, Eastern Region, Cameroon” International Journal of Advanced Research in Botany, vol.6,no.1,p.15-24,2020. http://dx.doi.org/10.20431/2454-9444.06001003

Copyright: (c) 2020 Authors. This is an open-access article distributed under the terms of the Creative Commons Attribution License, which permits unrestricted use, distribution, and reproduction in any medium, provided the original author and source are credited. 